\title{
Ebû Abdurrahman es-Sülemî. Kendilerini İbadete Adayan Sufi Kadınlar (Sufi Women Dedicated to Worship), trc. Doç. Dr. Ali Akay, İstanbul: İlk Harf Yaynları, 2012, 152 s. Dr. Melahat Beki*
}

Tasavvuf tarihi, insanlığı metafiziğin dikey boyutlarında yükselmeye çalışan, marifetullaha ${ }^{1}$ ulaşmayı hedef olarak ortaya koyan ve bu yolda ilerlemenin, yolun ve yolculuğun öğretilerini yaşatarak ve tecrübe ettirerek aşılayan birçok ünlü sufi ve evliyayla doludur. Ancak bu sufilerin mürşit ve müritlerini anlatan nice kitaplar, yaşayan nice ekoller, her zaman erkek sufilerin hiyerarşisinin söz konusu olduğu bir yapı betimlemektedir. Oysaki gerçek bundan ibaret değildir. Tasavvuf tarihinde birçok sufi kadın, bir mürşit olarak hizmet etmiş yahut ulvi bir şahsiyet olarak insan-ı kâmil kabul edilmiştir. Ne var ki bu kadınların ne isimleri ne de hayatları genellikle bilinmemekte, tabakat kitaplarında ise nadiren bazılarından bahsedilmektedir.

Bu yazıya konu olan "Kendilerini İbadete Adayan Sufi Kadınlar" kitabı, işte tam da bu noktada kadınların tasavvufun manevi hiyerarşisinde yükselip örnek sufiler olabileceklerine dair ön yargıları kıran ve 84 abide sufi kadının seçkin hayatlarını, sözlerini bir araya getiren bir çalışma olarak karşımıza çıkmaktadır. Kitabın yazarı Ebû Abdirrahmân Muhammed b. el-Hüseyn b. Muhammed es-Sülemî (ö. 412/1021) tasavvuf tarihinde Ebû Abdurrahman es-Sülemî olarak

* Marmara Üniversitesi Sosyal Bilimler Enstitüsü, Temel İslam Bilimleri Ana Bilim Dalı Tasavvuf Bölümü Doktora mezunu. Ülke Tv'de haber editörü.

1 Mutasavvıflara göre akıl ve naklin alanı dışında kalan hususlarda vasıtasız olarak elde edilen mârifet akıl ve nakil yoluyla elde edilen bilgiden daha değerli ve daha güvenilirdir. Böyle bir bilgiyle Allah’ı tanımaya "mârifetullah" (el-ilm bi'llâh), bu yolla Allah'ı bilen ve tanıyanlara da "ehl-i ma'rifet, ârif, ârif billâh, ehl-i irfân, âlim billâh" denir.

Ayrıntılı bilgi için bkz. Süleyman Uludağ, "Mârifet", TDV İslâm Ansiklopedisi, https://islamansiklopedisi.org.tr/marifet 
tanınan Horasanlı ünlü bir sufi müfessir ve muhaddistir. 325 (937) yılında Nîşâbur'da doğan Sülemî, başta dedesi olmak üzere dönemin tanınmış âlimlerinden ders almış; Irak, Rey, Hemedan, Merv ve Hicaz'a giderek buradaki âlimlerle görüşmüştür. Geniş bilgiye sahip olan, tasavvufun yanı sıra zâhirî ilimleri de iyi bilen Sülemî, bir yandan sufiler ve tasavvuf hakkında eserler yazarken öte yandan Nîşâbur'daki zâviyesinde irşat faaliyetini sürdürmüştür. Sohbetine katılan ve ondan hırka giyenler ${ }^{2}$ arasında Ebû Saîd-i Ebü'l-Hayr, Abdülkerîm el-Kuşeyrî, Ebû Nuaym el-İsfahânî, Ebû Abdurrahman el-Cüveynî, hadis âlimi Ahmed b. Hüseyin el-Beyhakī gibi ünlü mutasavvıf ve âlimler bulunmaktadır. Sülemî 3 Şâban 412'de (12 Kasım 1021) Nîşâbur'da vefat etmiştir.

Kaynaklarda Sülemîye 100'ü aşkın eser nispet edilir. Ancak bunların çoğu günümüze ulaşmamıştır. Sülemînnin eserleri ilgili olduğu ilimlerin ve özellikle tasavvufun en güvenilir kaynaklarından sayıldığı için son zamanlarda büyük önem kazanmış, eserleri üzerinde çalışılmış ve çeşitli baskıları yapılmıştır. Eserlerinin bir kısmı zahit ve sufilerin hayatına, bir kısmı da sohbet, melâmet, fütüvvet gibi tasavvufi konulara ve zümrelere dairdir. Kadın sufiler hakkında yazılan ilk eserlerden biri olan "Zikrü’n-nisveti'l-müte'abbidâti'ṣ-ṣuffiyyât" başlığıyla Arapça olarak kaleme aldığı bu kitabının günümüzde aynı dildeki tenkitli neşri Mahmûd Muhammed et-Tanâhî (Kahire 1993) ve Mustafa Abdülkādir Atâ (Beyrut 2003) tarafından gerçekleştirilmiştir. Eser ayrıca Sülemî ve kadın sufilere dair bir inceleme içeriğiyle Arapça metin ve İngilizce tercümesiyle birlikte yayımlanmıştır (trc. E. Cornell Rkia, Early Sufi Women, Louisville 1999). Meryem Hüseynî eseri Farsçaya çevirmiştir (Nuhustin Zenân-i Șafevî, Tahran 1385 hş.). İbnü'l-Cevzî, Șlfatü’s-Șafve’nin kadınlarla ilgili bölümünü, Abdurrahman-ı Câmî Nefehâtü̈l-üns'ün son bölümünü bu eserden faydalanarak yazmıştır. ${ }^{3}$

2 Ayrıntılı bilgi için bkz. Süleyman Uludağ, "Hırka", TDV İslâm Ansiklopedisi, https://islamansiklopedisi.org.tr/hirka

3 Ayrıntılı bilgi için bkz. Süleyman Uludağ, "Sülemî, Muhammed b. Hüseyin", TDV İslâm Ansiklopedisi, s. 53-55, https://islamansiklopedisi.org.tr/sulemimuhammed-b-huseyin (03.12.2021). 
Eserin Türkçe çevirisi ise Kendilerini İbadete Adayan Sufi Kadınlar adıyla, Dr. Mahmud Muhammed et-Tanâhînnin tahkiki ve Doç. Dr. Ali Akay'ın tercümesiyle İlk Harf Yayınevi'nden çıkmıştır. Kitabın giriş bölümünde Tanâhî, metne ait ilk yazma hakkında okuyucuya ayrıntılı bilgi vermiştir. Üzerinde çalıştığı yazma nüshasının boyutlarını, metni orijinalinden istinsâh eden müstensih ve müellif arasında geçen 62 yılı, bulduğu gramer hatalarını, yazının şekilsel özelliklerini risalenin doğru değerlendirilebilmesi için ihtimamla aktarmıştır. Sülemînnin bu risalesinin, pek fazla nakilde bulunulmayan, gün yüzüne çıkmamış bir eser olduğunu da belirtmiştir.

Eserin -tarihî bir yazma olmasının yanında en önemli özelliklerinden biri, tasavvuf tarihinde isimleri pek bilinmeyen birçok öncü sufi kadını, ailevi bağları, nesebi, eş ve çocuk ilişkileri gibi yönleriyle de ele almış olmasıdır. Alışılagelmişin dışında tarih ve terâcim kitaplarında fazlaca yer alamayan hususlardır. Bu abide kadınların nispet edildiği erkekler, zikredilen akrabalıklarla, samimi, seçkin kişilerdir. İçlerinde tâbiîn, muhaddis, sufi, hâkim, komutan olanlar vardır. Yûsuf b. Esbât, Hâlid b. Ma'dân, İsmâil b. Ayyâş, Hammâd b. Zeyd, Muhammed b. Sîrîn, Haccâc b. Yûsuf es-Sakâfì gibi isimler onlardan bazılarıdır. Ebû Osman el-Hîrî, Ebû Hafs en-Neysâburî, Ebû Süleyman ed-Dârânî, İbrahim el-Havvâs gibi şahsiyetler bahsi geçen sufilerin büyükleri ve ileri gelenleridir.

Kitabın Türkçe basımında seçkin sufi kadınların biyografileri -ulaşılabilir kaynaklarda olanlarının- kısaca verilmiş, bununla birlikte detaylı bilgi için başvuru kaynakları da dipnotlara eklenmiştir. Ayrıca bu sufi kadınlarla aralarında rabita olduğundan bahsedilen, sufi, muhaddis yahut alanlarında seçkin ve ünlü erkeklerin de biyografik bilgileri dipnotlarda kısaca yer almış, başvuru kaynakları hakkında bilgi verilmiştir. Türkçe tercümesi ve tahkikiyle 152 sayfalık bu veciz risale böylelikle meşhur tasavvuf ricalinin tarihini de tamamlamaktadır. ${ }^{4}$

4 es-Sülemî, Ebû Abdurrahman, "Kendilerini İbadete Adayan Sufi Kadınlar", tahkik: Dr. Mahmud Muhammed et-Tanâhî, trc: Doç. Dr. Ali, Akay, İlk Harf Yayınları, İstanbul,2012, s. 14. 
Tasavvufta manevi makamlara yükselmek için hakiki bir züht ehli olmak aşılması güç bir mertebeye erişmek demektir. Bu da mücahede, sabır, dünyayla ilişkiyi kesme, yatay boyutun tüm dünyevi menfaat ve lezzetlerinden yüz çevirip dikey boyutta ilahî olana yönelerek yükselmeyi gerektirir. Ancak tarih boyunca kadınların yer yer karşılaştığı ayrımcı ve küçümseyici bakış, tasavvuf tarihinde de ne yazık ki yer bulmuş, kadınların züht ehli olmak gibi hâllere güç yetiremeyeceği, dolayısıyla tasavvuf ve hâller ilminin sadece erkeklere ait bir ilim olduğu ön yargısı oluşmuştur. Sülemî’nin risalesi, erkeklerin tekeline aldığı ve uzun zaman kendilerini ayrı tuttuğu söz konusu olan bir alanda erken dönem Müslüman sufi Arap kadınlarindan şöhret bulmuş yahut pek bilinmeyen 84 tanesini zikrederek bu ön yargıyı yıkmaktadır. Tasavvufta yaşadıkları hâller, eriştikleri makamlar ve manevi ilimleriyle, züht dolu örnek yaşamlarıyla erkek-kadın tüm Müslümanlara örnek olan bu güzide kadın sufilerin bazıları aynı zamanda fakih veya muhaddis olarak bazıları ise tefsir ilmine dair çalışmalarıyla anılmaktadır.

Sülemî’nin kısaca bize tanıttığı bu sufi kadınların bir diğer ortak yönleri de tasavvufun ilk dönemlerinde -henüz kurumsallaşmış tasavvufun ortaya çıkmadığı dönemlerde- sufizmin özüne sıkı sıkıya bağlı olmalıdır. Ki, bu öz arada hiçbir aracıyı kabul etmeksizin direkt Kur'an'a ve Hz. Peygamber’in sünnetine sıkı sıkıya sarılmaktır. Örneğin Dımaşk abidelerinden Mümine bnt. Buhlul'a eriştiği manevi hâllerin kaynağı sorulduğunda "Resulullah'ın sünneti üzerine Allah'ın emrine uymaktan, Müslümanların hukukuna saygı göstermekten ve salih kişilere hizmet etmekten"5 diyerek tasavvufun sünnete bağlılığını ortaya koymaktadır.

Nîsâbur ehlinden, Fahreveyh bnt. Ali'den aktarılan şu söz ise kadın sufilerin manevi makamlara olan seyrüsüluk yolculuğunda, Allah'ın Kur'an'ın ve Sünnet'in önüne geçecek yahut onu perdeleyecek hiçbir aracıyı kabul etmediklerini çok güzel özetlemektedir: "Kim sebebi, Rabbine kavuşmada (vusul) itaate yapışmamak ve Resulüne tâbi olmamak için bir vesile yaparsa, O’na ulaşacak yolu 
bulmamıştır.”" Kitapta sufi abide kadınlardan nakledilenler bir yönüyle "sahih bir akidenin sahih yolu” hakkındaki sözlerdir.

Eserde yer alan sufi kadınların içinde en meşhuru Râbia elAdeviyye'dir. Kitap boyunca, ondan ve diğer birçok sufi kadından nakledilen sözlerin ortak noktası, kalplerinde Allah'tan başka sevgiye yer vermeyecek kadar züht sahibi olmaları ve gece gündüz ibadetle meşgul olarak, kendilerini ilahî aşka adamış olmalarıdır. Bu sufi kadınların, çevrelerindekilere öğüt ve tavsiyeleri de her daim bu minval üzerinde olmuştur. Kitapta yer alan biyografilerde bunu çok açık bir şekilde görmek mümkündür. Râbia el-Adeviyye’ye sorulan “Kulun kendisiyle Allah’a yaklaştığı şey nedir?” sorusu üzerine Râbia ağlayarak şöyle cevap vermiştir: "Bu soru benim gibi birisine mi soruluyor? Kulun kendisiyle Allah'a yaklaştığı şey, onun dünya ve ahirette O'ndan başkasını sevmediğini bilmesidir.”7 Bu abide kadınlar, dünya ve cennet nimetlerinden dahi yüz çevirmiş, kendilerini ilahî aşka ve fenaya erişerek vuslata adamışlardır. Onlar için, ölüm bu yüzden bir müjde, zühtle ve ibadetle geçirilen bir ömrün ardından gelen bir şeb-i arustur. Basra ehlinden sufi Abîde bnt. Ebî Kilâb’in bu minvalde şöyle dediği nakledilmiştir: "Takvâsı ve marifeti sahih olan için Rabbine kavuşması ve O’na varmasından daha sevimli bir şey yoktur."8

Sonuç olarak bu kitabın sufi kadınlar arasındaki abide şahsiyetlerden en seçkinlerini bir araya getirerek, onların yaşamları ve onlardan nakledilenleri gelecek nesillere taşıması, tasavvuf tarihinde kadının rolü ve ehemmiyetinin vurgulanması açısından oldukça önemlidir. Bazı sufi kadınların biyografilerine yahut hakkındaki bilgilere bir iki paragraftan fazla yer veremeyecek kadar kaynak sıkıntısı çekildiği aşikâr olsa da yine de bu küçük risalenin içeriği itibariyle literatüre mühim bir katkı sunduğunu söylemek mümkündür. Çünkü sufi erkeklere dair çok sayıda tabakat kitabı bulunduğu hâlde sufi kadınlara dair kitaplar nadirattandır ve genellikle başka

6 A.g.e., s. 89.

7 A.g.e., s. 34 .

8 A.g.e., s. 63. 
kitaplarda yer alan ufak alıntılardan ibarettir. 84 sufi kadına yer verilen bu kitap, tasavvuf tarihinde, mürşitlik yapabilecek nitelikte yahut yaşadıkları dönemde örnek şahsiyetleriyle şöhret bulmuş; bir insan-ı kâmil olma öğretisini sunan yaşamları ve ilimle marifetullaha giden yolda birer işaret taşı olmuş bu isimleri gün yüzüne çıkarmış ve gelecek nesillere aktarmıştır. Kadının tasavvuftaki yeri ve rolü konusundaki erkek egemen ön yargıların aşılması açısından da bir mihenk taşı olacak denli kıymete haizdir. 